\title{
The Influence of Board of Commissioners, Board of Directors, Board of Commissioners Independent Audit Committee and Board of Trustees to Financial Performance Islamic Banking (Case Study on Islamic Bank Period in 2011-2013)
}

\author{
Slamet Riyadi \\ University lecturer, August 17, 1945, Surabaya, Indonesia \\ Cahyo Budi Santoso \\ University lecturer, Riau Kepulauan, Batam, Indonesia
}

\begin{abstract}
In practice, BAZNAS or LAZNAS also manages the funds in the form of baitu qiradh (productive economic empowerment), lend funds to productive effort. Thus governance applied by the Organization Manager Zakat have characterized the governance of non-profit organization. The data presented in this section of the research about the management of Zakat based on existing regulations. This indicates that management of zakat more advanced and evolved over the development of other Islamic instruments. The purpose of this study is to The Influence of Board of Commissioners, Board of Directors, the Board of Commissioners Independent, the Audit Committee and the Board of Trustees to the Financial Performance Islamic Banking. The independent variable in this study is Board of Commissioners, Board of Directors, the Board of Commissioners Independent, the Audit Committee and the Board of Trustees, while the dependent variable is the Financial Performance (Y). The sample in this study is eight Islamic Banking (period in 2011-2013). Method of data processing is using multiple linear regression with SPSS. The result of Discussion can be concluded that:The results showed that the perspectives or paradigms about the importance of remuneration or the material world to increase commitment and performance are not as expected by the Maspion Company and employee commitment decreased significantly which may be caused by The Board of Commissioners do not affect financial performance significantly to Islamic banking. The Board of directors do not affect financial performance significantly to Islamic banking. Independent Commissioners have no effect significantly to financial performance of Islamic banking. Audit Committee financial performance significantly to the influential Islamic banking. The Board of Trustees has no effect significantly to financial performance of Islamic banking
\end{abstract}

Keywords: Board of Commissioners, Board of Directors, Board of Commissioners Independent, Audit Committeem Board of Trustees and Financial Performance

\section{INTRODUCTION}

Banking is one of the strategic role in align and balancing elements in the field of economic development. The strategic role of the bank caused by factors as a vehicle that can gather and transmit the funds of the community effectively and efficiently. The banking sector is becoming a mainstay in the field of economic development. The Bank is the artery of a nation's economy, so there is a problem in the world of banking will be devastating to the economy. Therefore the role of the banks is enormous for the economy for equitable development.

Banking is growing very rapidly after deregulation in finance, monetary, and banking in June 1983. The deregulation has resulted in the need of funds directly or indirectly through banking. 
These conditions encourage growth of our banking banking products is concerned, both the number of the bank or bank branch number which in turn more and more to reach the communities that need banking services.

Banking as an institution of the Community trusts play an important role in the economy, so that it can be said that the bank is at the heart of the financial system that might receive deposits from the public at large in the next passed on in the form of credit. As a business entity engaged in the services of the trust becomes even more important for all parties concerned, both for owners and managers of the bank as well as the community of users of the service of the bank.

The era of the gobal banking business environment demands the development of a more dynamic, competitive and fast changing. This demands the host management practices a healthy bank in accordance with the principle of prudence and the principle of good corporate governance principles, namely transparency, accountability, responsibility, independency and fairness (Regulation Bank Indonesia No. 8/4/PBI/2006, 2006). One of them is by setting a control system that aims to acquire the confidence that the interests of the community the depository bank, the Fund and bank service users could be preserved and organized effectively and efficiently.

Bank as one of the components of the economy who was instrumental in the economic ertumbuhan, where the bank involves many parties and exposed to many risks in practice. In addition to that on the other hand banks should have the capability of maintaining the trust of stakeholders, investors and the community against the bank, and therefore the implementation of GCG Principles to the world of banking is necessary in order to have an impact long term. The application of corporate governance is becoming one of the bank's efforts to emphasize the rights of shareholders to obtain information with timely, correct, accurate and transparent.

The bank's obligations in terms of disclosing all the information the financial performance of the bank. Then open or closed companies should be looking good corporate governance not only as mere accessories, but as an effort in terms of the increased efforts of the company's performance and value. Based on the background of the problems that have been raised above, then the researcher is interested in untukmeneliti with the title "the influence of Board of Commissioners, Board of Directors, the Board of Commissioners are independent, the audit committee and the Board of Trustees of Sharia against the financial performance Islamic banking (case study on Islamic Bank period in 2011-2013).

\section{LITERATURE REVIEW AND HYPOTHESIS}

\section{Good Corporate Governance (GCG)}

A Good Corporate Governance system in order to control and direct the company. According to Kaihatu (2006), principles of GCG include the following: 1. Transparency that openness in the decision-making process and openness in relevant and material information suggests about the company. 2. Accountability, namely clarity of function, structure, systems and accountability organ company so that the company's management to be implemented effectively. 3. Responsibility, namely compliance in the management of the company against the principle of a healthy Corporation as well as the legal regulations that apply. 4 . Independency is a State in which the company is managed professionally without a conflict of interest and the influence of the management which was not in accordance with the applicable laws and regulations and the principles a healthy Corporation. 5. Fairness (equity and reasonableness), fair treatment and equal in fulfilling the stakeholder's rights arising under the Treaty and regulations perusangan that applies GCG is a system of management the company 
Riyadi, S., \& Santoso, C. B. (2018). The Influence of Board of Commissioners, Board of Directors, Board of Commissioners Independent Audit Committee and Board of Trustees to Financial Performance Islamic Banking (Case Study on Islamic Bank Period in 2011-2013). Archives of Business Research, 6(5), 168-177.

designed to improve company performance, protect the interests of stakeholders and improve compliance with laws and regulations as well as the ethical values that apply in General.

GCG is a corporate governance describes relationships between various participants within the company that determines the direction and performance of the company. According to The Indonesian Institute for Corporate Governance (Darmawati, 2004; in 2008, Simon), the benefits of implementing GCG are:

1. Minimize the Agency Cost for these shareholders must bear the costs incurred as a result of the delegation of authority to management. These costs can be a disadvantage because management is using company resources for personal gain in the form of cost control must be issued the company to prevent the occurrence of such a thing. Costs this is called Agency Cost. With the preparation of the structure and functions of the Division are good, these costs can be pressed as low as possible.

2. Minimize the Cost of Capital of the company are managed well and healthy will create a positive reference for the creditors. This condition is very instrumental in minimizing capital costs to be borne when the company filed for a loan. This, in addition to strengthening the financial performance, will also make the company's products released to the market becomes more competitive.

3. Increase the value of the company's stock well managed companies that will interest investors to infuse capital. One of the main factors that were assessed before investors decided to buy shares is the quality of the Board of Commissioners. This can be seen on investors who invested in a long period of time.

4. Lift the image of the company's shareholders will be satisfied with the performance of the company as it will enhance the shareholders value and dividends.

Bank Indonesia also has issued several regulations, among others, transparency about the financial condition of the bank and increase of the external auditor. Banks are required to disclose the non performing loan (NPL), shareholders and affiliates, the practice of risk management in financial reporting (Kaihatu, 2006).

\section{Financial Performance}

Financial performance is the determination of specific measurements that can measure the success of a company in generating profits. A measuring instrument is required to examine the company's financial performance in assessing whether a financial performance had already reached his goal. Balanced also became one of the company's performance. Balanced performance card represents a system for measuring performance based on evaluating the organization development and growth, and enhancing its abilities with the goal to improve the customers satisfaction and the organizational effectiveness and efficacy (Poureisa, Ahmadgourabi, and Efteghar, 2013 in Gamal and Soemantri, 2017). The Balanced Scorecard is used as a measurement tool in order to measure an organization's performance in both public and private sectors to achieve the key business strategies and objectives (Astuti, Widari, Pelitawati, and Gamal, 2017).

The financial performance of banking is an important element to measure the success rate of GCG. Through an assessment of the financial performance, managers can determine the financial structure of the company better. Along with the increasing needs of financial information, particularly as the assessment of the financial performance, financial performance gauges in this study using profitability consisting of Return of Assets (ROA). The performance of bank is important things that must be accomplished by any company anywhere, because the 
company's performance is a reflection of the company's ability to manage and allocate funding sources. Profitability ratio is the ratio that measures how the company's rate of return compared with the sales, investment assets, and ekuitasnya. (Gitman, 2009:65-69).

ROA is the ratio to measure the return on total assets. ROA is calculated in the following way:

Return on Assets $=\frac{\text { Earning After Tax }}{\text { Average Assets }}$

\section{The Board of Directors}

the Board of Directors is a person who is appointed to lead the company. The Board of Directors can someone have the company or professional person appointed by business owners to launch and lead the company. The Board of Directors in a company will determine the policies to be taken or the corporate strategy in the short term and long term. The importance of the Board (both the Board of directors or the Board of Commissioners) are then raises a new question, how many of the Board that the company does with more and more Council means the company can minimize the Agency between the holder of the shares with the Board of Directors? The number of large profitable company Board from the viewpoint of the dependent resources (Mintzberg, 1983) in Fauzi (2016).

\section{The Board of independent Commissioner}

Fama and Jensen in Fauzi (2016) stated that non-executive director (independent Commissioner) can be act as a mediator in the dispute between the internal managers and oversees management policies as well as giving advice to management. The independent Commissioner is the best position to carry out the monitoring functions so that the created companies that are good corporate governance. Wallace and Peter in Fauzi (2016) company that has the proportions of members of Board of Commissioners who come from outside the company or outside director can influence management actions.

\section{The Board of Directors}

The Board of Directors acts determine the policies to be taken or starategi the company in the short term and long term. The number of large profitable company Board from the viewpoint of resources dependence (Goodstein, Gautarn, Boeker, 1994) in Fauzi (2016). The company will be helped by the dewannya to be able to manage its resources better. Effective corporate governance in Islamic banking is supported by the Member of the Board of directors who has a reputation of good moral and technical competencies that support. The responsibilities of the position on the Board of Directors of several management functions without having to be directly involved in the management of operasionalisasi bank, so he should have an agenda of regular meetings with all components of the company, as well as having the function of the effective control.

\section{Board of Trustees}

Board of Trustees compliance has become an important pillar of the existence of the Islamic banking entity. The application of shariah compliance it is the existence of the Sharia Supervisory Board (DPS). Sharia Supervisory Board is an independent agency or judges specialized in fiqh muamalat. However, DPS can be also members of outside expert fiqh but also experts in the field of Islamic financial institutions and fiqh muamalat. Obligations of the Sharia Supervisory Board to direct, meriview and oversees the activities of financial institutions in order to be assured that they comply with the rules and principles of Islamic jurisprudence.. 


\section{Hypothesis}

$\mathbf{H}_{1}$ : The Board of Commissioners of influential financial performance significantly to Islamic banking.

$\mathbf{H}_{2}$ : The Board of Directors financial performance significantly to the influential Islamic banking.

$\mathbf{H}_{3}$ : The Board of Commissioners are independent financial performance significantly to the influential Islamic banking.

$\mathbf{H}_{4}$ : Audit Committee financial performance significantly to the influential Islamic banking.

$\mathbf{H}_{\mathbf{5}}$ : The Board of Trustees of Islamic financial performance significantly to the influential Islamic banking.

\section{Analysis Model}

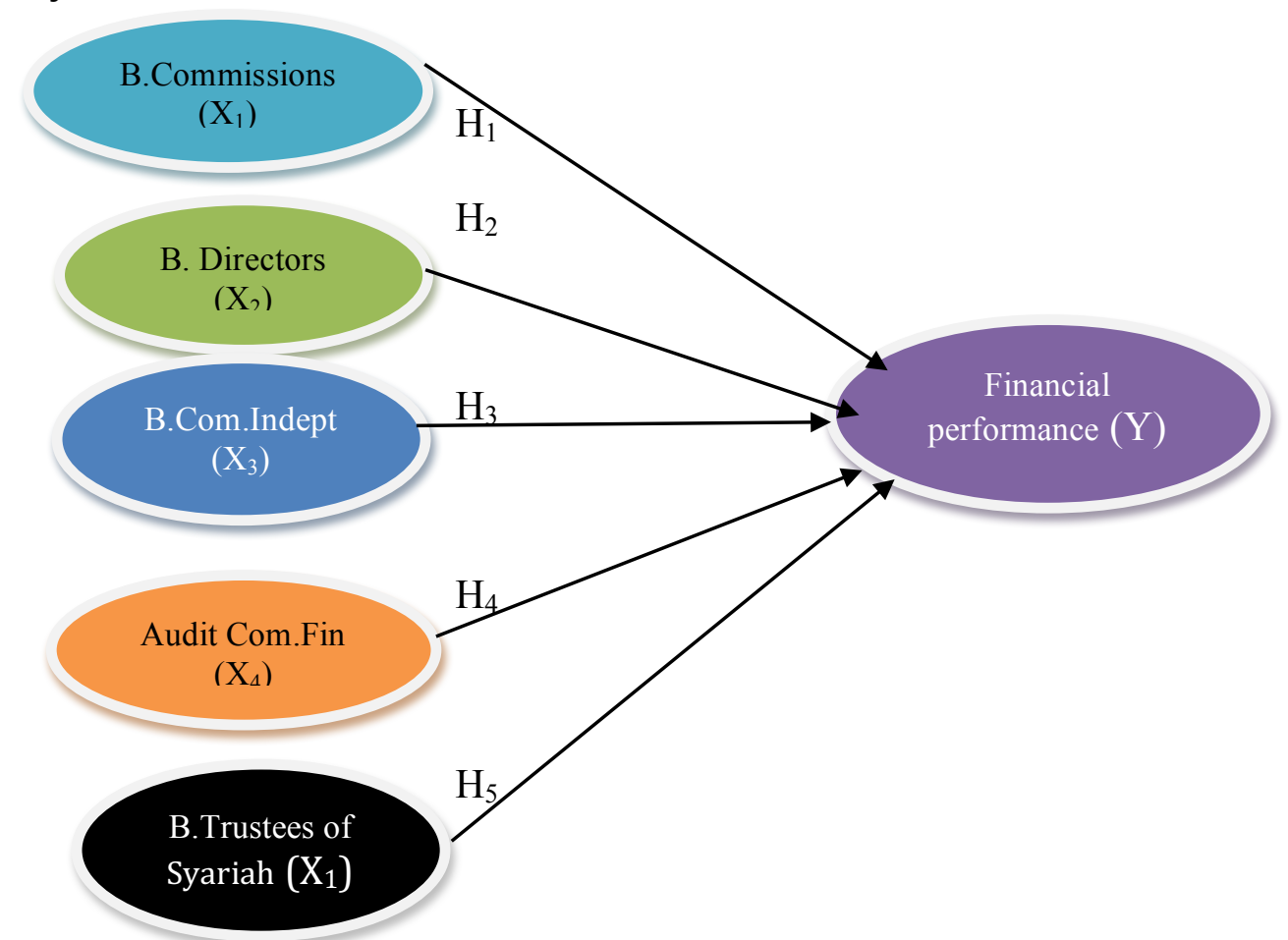

Figure 1. Analysis Model

\section{RESEARCH METHODS}

This research is quantitative research using data time series and cross section of the years 2011 to 2013. Research data that includes data for the period 2011 to 2013 is seen fairly represent the condition of Islamic banking in Indonesia at that time and financial indicators Islamic banking in that period. The population in this research is the Board of Trustees Bank in Indonesia which is listed in Bank Indonesia, with criteria: 1. the Board of Trustees Bank based on Shariah banking statistics published Bank Indonesia per-December 2013. 2. The financial statements and the report of GCG during the period of 2011-2013. 3. Data about the company's Corporate Governance as well as the financial performance data for Islamic banking).

\section{Variable Observed}

This study uses several variables, which include:

a. The dependent variable is financial performance 
b. The independent variable is Board of Commissioners $\left(X_{1}\right)$, Board of Directors $\left(X_{2}\right)$, Board of Commissioners are independent $\left(\mathrm{X}_{3}\right)$, audit Committee $\left(\mathrm{X}_{4}\right)$ and Board of Trustees $\left(\mathrm{X}_{5}\right)$.

\section{Technique of Data Analysis}

The data were analyzed using multiple linear regression assisted by SPSS software version 23 . The steps undertaken to analyze the research data are as follow:

$Y=a+\beta_{1} X_{1}+\beta_{2} X_{2}+\beta_{3} X_{3}+\beta_{4} X_{4}+\beta_{5} X_{5}+e$

$\mathrm{a}=$ constant

$\beta_{1,2,3,4,5}=$ Constant of independent variable

$\mathrm{Y}=$ Financial performance

$\mathrm{X}_{1}=$ Board of Commissioners

$\mathrm{X}_{2}=$ Board of Directors

$\mathrm{X}_{3}=$ Board of Commissioners are independent

$\mathrm{X}_{4}=$ Audit committee

$\mathrm{X}_{5}=$ Board of Trustees

$\mathrm{e}=$ error term

\section{Classical Assumption Test}

Classic assumption test aims to determine whether the regression model shows a significant and representative association. The classical assumption used are (Ghozali,2007: 110): Normality Test, Autocorrelation Test, Heterocedastity Test and Multicolinearity Test

\section{Test The Hypothesis}

a. F Test (Simultan), F tested to find out whether free variables together had a significant influence towards the dependent variable (Ghozali, 2007:84).

b. Test (partial), t-test was used to test the influence of the magnitude of one variable against the free variable (Ghozali, 2007:85).

\section{ANALYSIS AND DISCUSSION}

Following are the results of a test for normality with the normal probability plot:

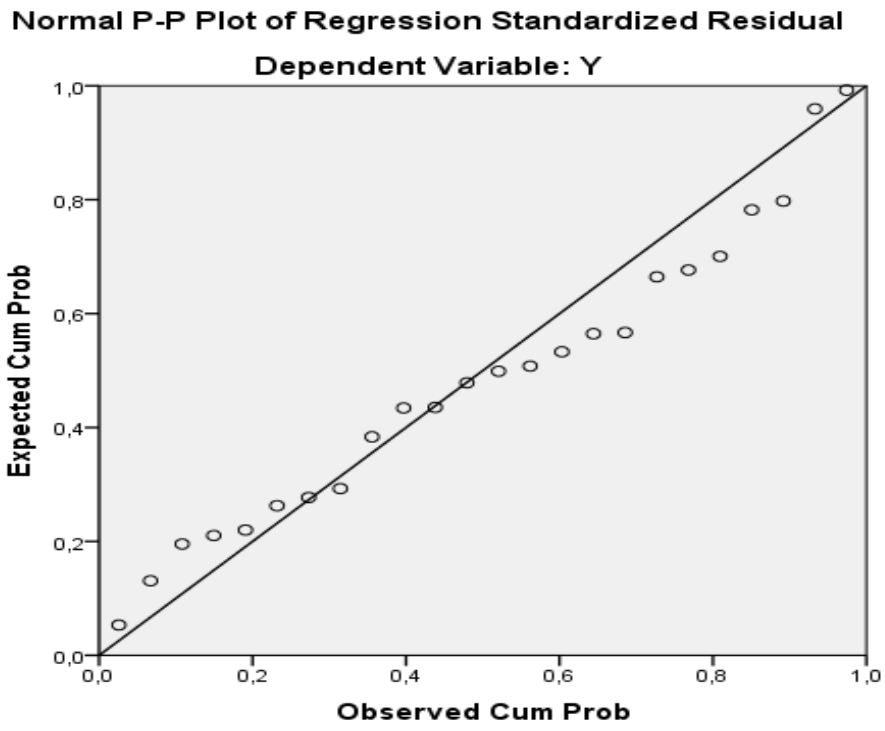

Figure 1 Test for Normality Probabilty

From Figure 1 it can be noted that the points accumulated around the diagonal lines, so that 
the residual regression model is summed up following a normal distribution.

\section{Multicollinearity Test}

Following are the results of the test using SPSS program multicollinearity:

Table 1. Multicollinearity Test

\begin{tabular}{|c|c|c|c|}
\hline Variable & Tolerance & VIF & Description \\
\hline $\mathrm{X}_{1}$ & 0,598 & 1,672 & Free Multicollinearity \\
\hline $\mathrm{X}_{2}$ & 0,614 & 1,629 & Free Multicollinearity \\
\hline $\mathrm{X}_{3}$ & 0,949 & 1,054 & Free Multicollinearity \\
\hline $\mathrm{X}_{4}$ & 0,606 & 1,651 & Free Multicollinearity \\
\hline $\mathrm{X}_{5}$ & 0,535 & 1,869 & Free Multicollinearity \\
\hline
\end{tabular}

The table 1 shows the value of the variable tolerance of rewards, opportunities, self-efficacy and knowledge entrepreneurship $>0.1$, similarly VIF $<10$, so multicollinearity does not occur can be summed up in the regression model.

\section{Heteroskedastisitas Test}

Following are the results of the test of heteroskedastisitas with a scatter plot using the SPSS program:

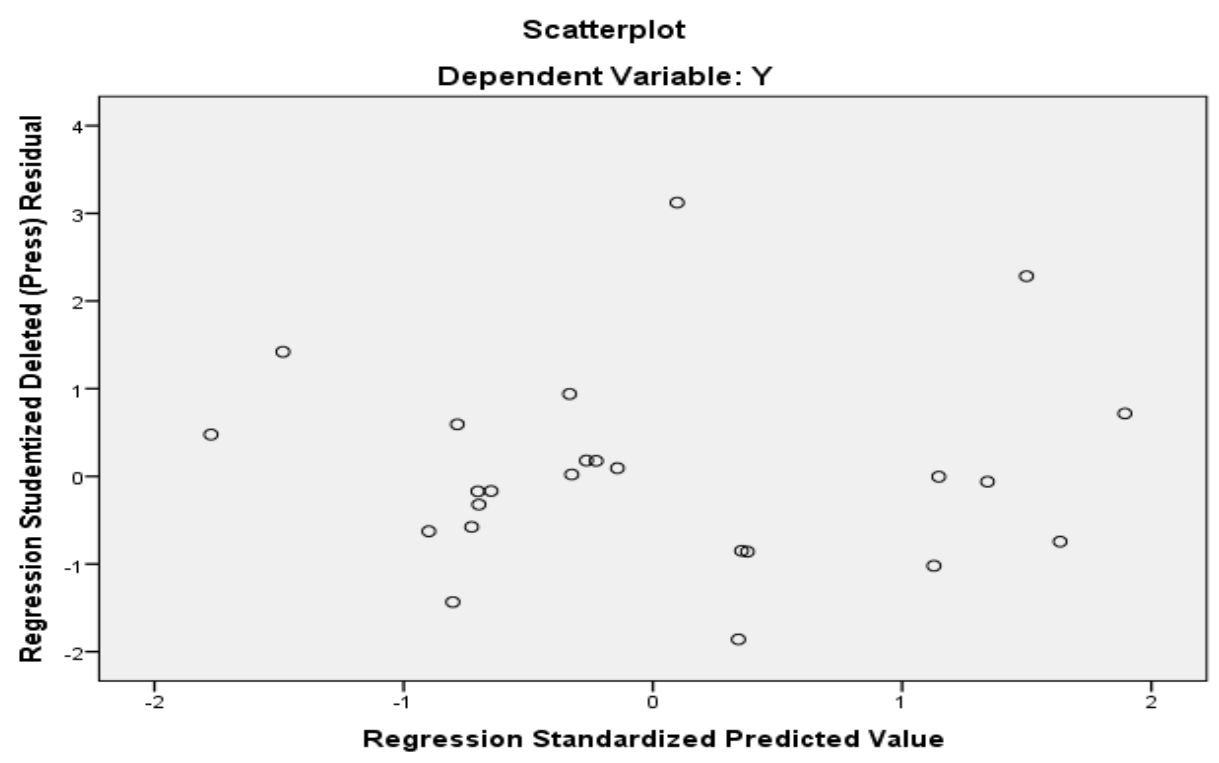

Figure 2 Test Heteroskedastisitas with a Scatter Plot

Figure 2 shows the points do not form a specific pattern and below zero on the $\mathrm{Y}$ axis, so that it can be concluded does not occur heterokedastisitas in model regression.

\section{Analysis of The Multiple Linear}

Linear regression test Results Table Double of the value of unstandardized's ( $\beta$ ) produced multiple linear regression analysis regression equation is obtained as follows: from the above equation, the values of linear regression coefficients of compounds can be described as follows:

1. $\alpha=0.311$,-means that the magnitude of financial performance $(\mathrm{Y})$ was 0.311 assuming variables $\left(\mathrm{X}_{1}\right)$, Board of Commissioners, Board of Directors $\left(\mathrm{X}_{2}\right)$, the Board of Commissioners are independent $\left(\mathrm{X}_{3}\right)$, audit Committee $\left(\mathrm{X}_{4}\right)$ and Board of Trustees $\left(\mathrm{X}_{5}\right)$ is zero. 
2. $\mathrm{X}_{1}=0.012-$ means that if the status Board the Commissioner down one unit then financial performance will be up by 0.012 unit assuming a variable $\left(\mathrm{X}_{2}\right)$ Board of Directors, the Board of Commissioners are independent $\left(\mathrm{X}_{3}\right)$, audit Committee $\left(\mathrm{X}_{4}\right)$ and Board of Trustees $\left(\mathrm{X}_{5}\right)$ is constant.

3. $\mathrm{X}_{2}=0.053$ meaning if the Board of Directors $\left(\mathrm{X}_{2}\right)$ up one unit then financial performance will rise of 0.053 unit assuming variables $\left(\mathrm{X}_{1}\right)$, Board of Commissioners, the Board of Commissioners are independent $\left(\mathrm{X}_{3}\right)$, audit Committee $\left(\mathrm{X}_{4}\right)$ and Board of Trustees $\left(\mathrm{X}_{5}\right)$ is constant.

4. $X_{3}=0.021$ meaning if status of Board of Commissioners are independent $\left(X_{3}\right)$ up one unit then financial performance will be up by 0.021 unit assuming variables $\left(\mathrm{X}_{1}\right)$, Board of Commissioners, Board of Directors $\left(\mathrm{X}_{2}\right)$, audit Committee $\left(\mathrm{X}_{4}\right)$ and Board of Trustees $\left(\mathrm{X}_{5}\right)$ is constant.

5. $\mathrm{X}_{4}=0.491$ meaning if the audit Committee $\left(\mathrm{X}_{4}\right)$ up one unit then financial performance will be up by 0.491 unit assuming variables $\left(\mathrm{X}_{1}\right)$, Board of Commissioners, Board of Directors $\left(\mathrm{X}_{2}\right)$, the Board of Commissioners are independent $\left(\mathrm{X}_{3}\right)$, and Board of Trustees $\left(\mathrm{X}_{5}\right)$ is constant.

6. $\mathrm{X}_{5}=0.081$ - meaning if $\mathrm{f}$ the Board of Trustees $\left(\mathrm{X}_{5}\right)$ down one unit then financial performance will be up by 0.081 unit assuming variables $\left(\mathrm{X}_{1}\right)$, Board of Commissioners, Board of Directors $\left(\mathrm{X}_{2}\right)$, the Board of Commissioners are independent $\left(\mathrm{X}_{3}\right)$ dam of the audit Committee $\left(\mathrm{X}_{4}\right)$ is constant.

\section{Hypothesis Test Simultaneously (F Test)}

Following are the results of the simultaneous trials (test F) using the SPSS program:

Table 2. Simultaneous Test (test F)

\begin{tabular}{|l|c|c|c|c|c|}
\hline \multicolumn{1}{|c|}{ Model } & Sum of Squares & $d f$ & Mean Square & $F$ & \multirow{2}{*}{ Sig. } \\
\cline { 1 - 4 } Regression & 8,541 & 5 & 1,708 & & \multirow{2}{*}{2,882} \\
\cline { 1 - 4 } Residual & 10,668 & 18 & 0,593 & \\
\cline { 1 - 4 } Total & 19,209 & 23 & - & & \\
\hline
\end{tabular}

Based on the test results table $\mathrm{F}$ obtained $\mathrm{F}$ count of $52.875>$ Sig, with a value of significance of 0.05, then $<0.000$ Ho denied and summed up the Board of Commissioners $\left(\mathrm{X}_{1}\right)$, the Board of Directors $\left(\mathrm{X}_{2}\right)$, the Board of Commissioners are independent $\left(\mathrm{X}_{3}\right)$, audit Committee $\left(\mathrm{X}_{4}\right)$ and Board of Trustees $\left(\mathrm{X}_{5}\right)$ are jointly significant influential financial performance (Y) Islamic banking. This means financial performance $(\mathrm{Y})$ is the same with will improve financial performance $(\mathrm{Y})$. Based on the results obtained in this Board of Commissioners who suspect $\mathrm{H} 1\left(\mathrm{X}_{1}\right)$, the Board of Directors $\left(\mathrm{X}_{2}\right)$, the Board of Commissioners are independent $\left(\mathrm{X}_{3}\right)$, audit Committee $\left(\mathrm{X}_{4}\right)$ and Board of Trustees $\left(\mathrm{X}_{5}\right)$ have a positive influence on performance together and finance $(\mathrm{Y})$ can be accepted.

Following are the results of the test are partial (test- $t$ ) use the program SPSS:

1. The influence of Board of Commissioners $\left(\mathrm{X}_{1}\right)$ against the financial performance (Y) yields a value of $0.853>0.05$ significance, then Ho was accepted and it was decided the Board of Commissioners has no effect on performance of Finance (Y) Islamic banking. There is no influence of the Board of Commissioners against the financial performance is shown by the regression coefficient values of 0.012 .

2. The influence of the Board $\left(\mathrm{X}_{2}\right)$ against the financial performance $(\mathrm{Y})$ yielding the value significance of $0.442>0.05$, then Ho accepted and decided upon the Board of Directors does not have an effect on financial performance. There is no influence of the Board against the financial performance is indicated by the value of the regression coefficients 


$$
\text { of } 0.056 \text {. }
$$

3. The influence of Board Commissioners are independent $\left(\mathrm{X}_{3}\right)$ yerhadap financial performance $(\mathrm{Y})$ yielding the value significance of $0.068>0.05$, then Ho was accepted and it was decided the independent Commissioners have no effect significantly to financial performance. There is no influence of the Board of Commissioners are independent of financial performance is shown by the significance of the regression coefficient values of 0.021 .

4. The influence of the audit Committee $\left(\mathrm{X}_{4}\right)$ against the financial performance (Y) yields a value of significance of $0,043<0.05$, then Ho denied and it was decided the audit committee in a positive and significant effect on performance. Influence on performance of financial audit committee is significance demonstrated with regression coefficients of 0.491 .

5. The Influence of Board of Trustees $\left(\mathrm{X}_{5}\right)$ against the financial performance $(\mathrm{Y})$ yielding the value significance of $0.173>0.05$, then Ho accepted and Board of Trustees decided not to affect financial performance. There is no influence of Board of Trustees against financial performance is indicated by the value of the coefficient of regression-0.081.

\section{CONCLUSIONS AND SUGGESTION}

\section{Conclusions}

Result of analysis and discussion can be summarized as follows:

1. The Board of Commissioners do not affect financial performance significantly to Islamic banking.

2. The Board of directors do not affect financial performance significantly to Islamic banking.

3. Independent Commissioners have no effect significantly to financial performance of Islamic banking

4. Audit Committee financial performance significantly to the influential Islamic banking.

5. The Board of Trustees has no effect significantly to financial performance of Islamic banking

\section{Suggestion}

1. Company's Shariah-based banking sector can serve as a reference for the company to further improve the functions, duties and independence of each so that it can improve the quality of GCG in order to improve financial performance.

2. Researchers, as a means to gain insight and experience as well as knowledge about the practice of GCG in the Islamic financial institutions.

\section{References}

Astuti, H. K., Widari, N. S., Pelitawati, D., \& Gamal, A. 2017. The College Management Performance is Reviewed from the Perspective of Customers and Financial Perspective (A Case Study On University WR Supratman Surabaya). Archives of Business Research, 5(12), 180-190.

Fauzi. N.A. 2016.Influence on performance of GCG financial (studies on bankumum syraiah Indonesia 2011-2015 Years). Thesis. Financial Management courses are Banking State Islamic Institute of Syriah Surakarta.

Gamal, A. and Soemantri, A.I., 2017. The Effect of Balanced Scorecard on the Private College Performance (Case Study at the University of WR Supratman Surabaya). Archives of Business Research, 5(5), 126-134.

Ghozali, I. 2013. The application of Multivariate Analysis With SPSS Programme 21 (7th ed.). Semarang: University Of Diponegoro.

Kaihatu, t. s., 2006, Good Corporate Governance and its application in Indonesia, Journal of management and entrepreneurship, Vol 8 No. 1 March scented, a. m. c., 2010, analysis of profit and financial performance 
Management Corporate Acquirer both before and after the Merger and Acquisition of listed on the Indonesia stock exchange Years 2008-2009, Thesis, Faculty of Economics, Universitas Diponegoro.

Santoso, Cahyo Budi, 2017. Zakat Organization as the Fourth Sector. International Journal of Economics and Finance; Vol. 9, No. 12. Canadian Center of Science and Education.

Uyanto, Stanislaw s. 2009. Data analysis with SPSS manual (3rd ed.). Yogyakarta: Graha. 